\title{
International Terrorism Challenge of Time
}

\author{
Dr. Adrian LEKA \\ "Luigj Gurakuqi" University \\ Faculty of Law
}

\begin{abstract}
Through this paper, I do not aim to reflect and explain everything as it is more widespread than what it is thought, but what I want to convey is terrorism as a criminal act of the highest form and barbarism, once and for all should be identified so it can be combated. The fight against crime, undoubtedly constitutes one of the greatest challenges faced by today's society. Terrorism is a form of equally young and old crime manifested in different forms which today poses a threat to global security. The phenomenon of terrorism has become a major concern of the international community and countries around the world. Terrorism flies and stems like waves, at some point collides brutally with our lives and then withdraws by hiding as if nothing had ever existed, to strengthen and then hit again. Conflicts and wars have followed humanity from antiquity to the present day. One of the global challenges in the present time is international terrorism. Currently there are many social and forensic sciences who study terrorism as criminology, penology, global sociology, conflict sociology, religious sociology, political science etc. After Sept. 11, international terrorism became the central theme in the context of security and world peace. Border control was increased. The Americans experienced the feeling that everything they had been building for years was destroyed overnight. More and more today, we hear about terrorist acts. It is impossible to browse the newspaper and not find something that has no content for terrorism. These are modest reasons and incentives to explore and reflect on international terrorism as a real tendency to resist. However, it appears that international terrorism has reached multidimensional dimensions, it includes terrorist behaviors, causes and reasons for the occurrence of terrorist acts, the social context in which they may arise, research methodology of terrorism recognition, how to prevent and control terrorist acts, etc. Despite the commitment that I have indicated, I am aware that I have not been able to touch all the nuances of international terrorism, so all suggestions are welcome.
\end{abstract}

Keywords: International Terrorism Challenge of Time.

\section{Introduction}

\section{Origin of International Terrorism.}

Although this concern has arisen in the XVIII century, methods have always existed. Terrorism as a political war method consists in using the tools of violence in its most drastic forms, presented since ancient times, we can say that along its dynamics, terrorism has gone through these periods.

\section{Ancient period.}

In the period of the tyrants murders in ancient states, terrorism is used in the fight against tyranny and the tyrants. The theory of assassination of the tyrants presents reasoning of the tyrants' murder for political reasons trying to differentiate it from the struggle for power. Such acts as the murder of Hiparit, tyrant of Athens in 514 A.D conducted by Harmodi and Aritogeitoni etc.

\section{Terrorism of the XIXth century.}

Terrorism in the XIXth century and the introduction of anarchists until the XIXth century, the main and almost only form of terrorism was the assassination of leading figures like kings, emperors, then attacks were directed against church leaders, senior military officers, individuals with diplomatic functions as well as against other public figures, with particular impact on the current policy of the given country. The beginning of the XIXth century, when the means and methods of conducting, organization of individuals who commit such killings were perfected and raised to a higher level. 


\section{Terrorism of the XXth century.}

At the beginning of the century, due to the tradition there is a consistency of appearance of terrorism, again with the face of murder of contemporary political figures in many countries such as Spain, Russia, USA, Germany, Italy. Generally, at this time terrorism was a national trend but starting from the period between the two World Wars and especially after incessant wars in the Middle East, international terrorism was observed and took place.

\section{New terrorism.}

The new terrorism differs from known forms now and not only by its international character, but because it also uses electronic network and sophisticated technology thus ensuring freedom from restrictions and is designed far from traditional terrorism. This type of terrorism in the unconsolidated democracies still has some political support. The new terrorists are very well organized and appear inclined to unlimited violence and suicidal acts to eliminate a large number of people.

\section{Causes of terrorism.}

The causes of terrorism constitute a certain objective circumstance that appear before motives and in one way or another affect the motives of the author of terrorism, and here causes must be distinguished from motives, which in themselves represents internal intention of the author of the terrorist acts that can be impulsive, emotional, moral, other effects resulting from his psychic ${ }^{1}$.

\subsection{Conflicts through certain social groups on ethnic or national grounds.}

Conflicts through certain social groups on ethnic or national grounds, as the cause of terrorism, we can mention the situation created after the Second World War, as a result of the new definition of international borders and the creation and dissolution of various national states with millions people remaining outside their native countries ${ }^{2}$, such a situation is encountered, for example in South Asia, where the government of Great Britain after World War II was prepared to withdraw from some of the colonized territories, etc.

\section{Conflicts between certain social groups on religious grounds.}

Conflicts between certain social groups on religious grounds, as the cause of terrorism, we can take as an example the wars that operated in XXth century in Lebanon, which were wars between two religious regions and acted in the name of Allah ${ }^{3}$.

\section{The difference of National Terrorism with the International Terrorism.}

The difference between national terrorism and the international one, rather than a legal fact is conceptual, because the nature of terrorism itself exceeds the boundaries of a state. International terrorism is characterized precisely to its extension in more than one state, therefore at least two, which will be attended by people from more than one country or territory of at least two states. Ndërsa në terrorizmin kombëtare personat i përkasin vete shtetit. Terrorism can be internal, international and sponsored by the supporting countries. International terrorism crosses the state borders, it is included in a geopolitical space and performed as an instrument to gain an immediate result or in a short time. Internal state terrorism on the borders of the state itself tends to manifest little secrecy. He is often performed openly. Sponsored terrorism by the supporting countries has external support, precisely at the state level. International terrorism is understood as something that exceeds the limits of national aims.

\section{Types of terrorism.}

\subsection{Traditional terrorism.}

Terrorists generally differ in their level of risk and degree of threat they pose in different countries, different periods of time, but there are some common areas in which they can be identified. They have at their disposal a wide variety of tactical

\footnotetext{
${ }^{1}$ Dr.sc. Haki Demolli,"Terrorism", Prishtine 2002, pg.104

2 Leonard Eeinberg dhe Paul Davis, cited work, pg.48

${ }^{3}$ Dr.sc. Haki Demolli, "Terrorism" Prishtine 2002, pg.105
} 
opportunities through which they can operate. The real potential of these terrorist groups to use WDM brings more opportunities and dire consequences ${ }^{4}$. Terrorism of this kind is called new terrorism and definitely shows the need for a comprehensive assessment of terrorist threats and tactics which can be grouped as traditional terrorism and the new terrorism. Five are the components of new terrorism: religious terrorism, ecological terrorism, narco-terrorism, nuclear, biological and chemical terrorism and computer terrorism or cyber-terrorism.

\section{New terrorism.}

Since the end of the Cold War and especially on the brink of the bombing of New York City, Oklahoma City and attacks in Japan, there has been a large increase in volatility and the threat of new terrorism ${ }^{5}$.

Chemical Terrorism, which may use agents and chemicals in order to cause massive disaster, despite technical issues to be included by chemical processes, such as sarin gas in Japan by the Aum Shinriko etc.

Biological Terrorism, may use biological agents to achieve mass death.

Radiological terrorism, where a group of terrorists could disperse radiological material in an attempt to infect a population, located in a certain geographic area ${ }^{6}$.

Nuclear Terrorism, which is a real danger of mass destruction posed by nuclear terrorism spectrum.

Terrorism agriculture, where pathogens for destruction of animals and crops, are easier to find than to create ammunition to kill.

Eco-terrorism, is similar to agriculture terrorism, is a threat to the environment and ecological system, it can easily damage the eco-system of a country causing destruction and immediate death to achieve their goals ${ }^{7}$.

Cyber-terrorism, cyber terrorism is a combination of terrorism and computer space, it is defined as a deliberate attack, political, motivated against information, systems or softwares, and data which follow in violence against targets of international groups or clandestine agents.

\footnotetext{
4 Paul Eilkinson, "The Strategic Implications of Terrorism", 5; marre ne http;//is.ci-cect.com

${ }^{5}$ Dr. Mgnus Ranstorp

6 Jim Walsh, "Nuclear Terrorism: Risks, Consequences, and Response" in "Countering Terorism: Dimension of Preparedness", fq.18

${ }^{7}$ Michal J. Stevens, "What is Terrorism and can Psychology do anything to Prevent it", fq.511, publikuar online in Eiley inter-scince www.interscience.eiley.com
}

\section{Terrorist Acts.}

\subsection{Interpretation of terrorist acts.}

For the interpretation of terrorist acts we have two theories:

Positivist theory

Post-positivist theory.

According to positivist theory derivative of attack is extracted directly by first strategic object to attack. Positivist theory focuses on the strategic object to make criticism. On the contrary post-positivist theory focuses on the audience, in this view to understand what the terrorists wanted to express by the attack, and why precisely that strategic object. Despite these theories to achieve their goals the terrorists carry out terrorist acts in various forms, through which they aim to hit their opponent or target ${ }^{8}$. 


\section{Forms of terrorist acts.}

The bombings are the main means of terrorist groups, more than half of the incidents and terrorist threats involve explosives and other terrorist tactics ${ }^{9}$.

Arson is another tactic that has been the favorite of some terrorist groups, for more than the last 20 -years almost $14 \%$ of all terrorist incidents have been the result of arson ${ }^{10}$.

Assassination is an early used tactic, the word assassination derives from Hashasin or Society of Assassin ${ }^{11}$.

Armed attacks have become increasingly more dangerous and more deadly than in the past ${ }^{12}$.

Kidnapping is an activity which has been applied later on by terrorists and most used in today's terrorism in the world.

8 Dr.sc. Haki Demolli, "Terrorism", Prishtine 2002, pg.196.

Abduction is a terrorist act that needs goods, except when terrorists operate in an environment like Beirut, as to maintain abducted victim and to assure and preserve the area where the abductees is closed, a large number of people is needed, and always exists or exacerbates the risk that where the abducted person is being held, can be detected by the authorities of the country where the victim is from.

Sabotage, is an effective terrorist tactic against industrialized countries used against those countries because they usually appear as highly vulnerable.

Threats can be an effective tool when used by an organized terrorist group or a state-sponsored terrorist group.

Hijacking and holding hostages, such as the hijacking of trains, the mass transportation, subway, aircraft etc.

Mass murder of civilians, the use of weapons and technology of mass destruction ${ }^{13}$.

\section{Nature of terrorism.}

\subsection{Islamic terrorism.}

Islamic terrorism can be distinguished from all other forms of terrorist action, mainly based on three specific ideological elements:

Islamic terrorism categorically rejects all other contemporary ideologies, the basic goal of Islamic terrorism is Islamic renaissance, which should bring not only the release of all Muslim territories from Western influences, but also the conquest of the whole terrestrial globe ${ }^{14}$.

${ }^{9}$ Karl A. Seger, The anti-terrorist handbook: A practical guide to counteraction planning and operations for individuals, businesses and government (Novato, Calofornia:Presidio Press,1990),pg.43. ${ }^{10}$ Ealter Laqueur, The age of terrorism (Boston:Little,Broen and Company),pg.14. ${ }^{11}$ Assassination, "source http://en.eikipedia.org.eiki/assassination.

12 Rex A. Hudson, "The sociology and psychology of terrorism", September 1999.

13 Richard Falk: Ending terrorism, published at "terrorism and political violence",from the editor Henry han SHBA,1993, pg.427.

Karakteristike tjetër është prezantimi i tij si formë e luftës së shenjtë e cila detyrimisht do të kurorëzohet me fitoren e plotë.

Elementi i tretë karakteristik është krijimi e rregullave të detyrueshme të sjelljes islame, është vrasja e armiqve të Zotit, armiqte tanë duhet të vriten, ndërsa të pafetë duhet ta zgjedhin vdekjen ose kthimin e tyre të detyrueshëm në fenë islame. 


\section{Western terrorism.}

With the collapse of the Soviet Union and other communist governments in Europe it was seen as a trend, the decline of international terrorist activities. This can be explained by the influence of communist ideology that made the communist propaganda in Western Europe for terrorists.

\section{War against terrorism.}

Is the disappearance of terrorism possible and how can this be done?

The West, who suffers from vertigo due to its material success, has allowed materializing and commercial superiority that comes along with it, to prevail over everything else. In the stories of all civilizations, man can face the evil. The war against the threat of terrorism therefore is at the top list of the agendas of most of the governments of countries in order to fight terrorism and to give solution to this problem. Terrorists today are no longer confined to their national borders, they operate from foreign bases with a wide and complex network with international connections. Modern technologies and the arrival of the information age enables them to become global operators with little effort. The fight against terrorism can not remain confined to national action programs; it requires a joint and well coordinated plan internationally, as well as international solutions.

14 The International Terrorism a legal critique nga Muhamed Aziz Shukri, Vermont 1991, pg.11.

The fight against terrorism is certainly not an easy task and it needs joint efforts by the governments of many countries and should involve many people as part of the plan. This will provide a common basis for international policy and action in support of such collective efforts as:

\section{The reaction to mind-set terrorism.}

The main objectives, prevention, obstruction, response and protection.

Prevention, is achieved by maintaining strong objectives.

Obstruction, which have been very important to combat terrorism worldwide.

Prediction of terrorist activities and events achieved through improved detection capabilities.

Levels, political / diplomatic level, anti-terrorism measures used to manage risk and tactical level.

State policies.

Soft-line methods.

Harsh Line Approach methods.

\section{Conclusions}

The term terrorism has been interpreted in many different ways, mainly depending on the viewpoint that takes the issue. It has gone through various transformations in new aspects. Terrorism includes acts of violence by groups of people with a political motive or purpose. Terrorism has existed in various forms since the early days of human civilization. Terrorism has now become more threatening and its acts more dangerous. The fight against terrorism is a very complex and difficult task because the terrorists are not a structured or specified enemy, it has an elusive nature which makes it even more difficult to cope with. One way to oppose terrorism ios the importance featuring the very clear understanding of the essence and objectives to oppose terrorism. Diplomacy also plays a crucial role in the development of this international issue. The fight against it can sometimes be simple, because the state can fight only against small terrorist groups, by issuing orders against them. An important tool used by terrorists to advance their cause is the media. The role played by the media is a wild aspect of the fight against terrorism, being in a time that all information are conveyed by the media. In the framework of the recommendations we enumerate: 
A clear and complete policy of the war against terrorism should be formulated by the state based on the understanding of the nature, type of terrorism and risk analysis.

A national policy against terrorism must have cooperation and international links because most of the terrorist activities today have international connections.

A joint plan of action determined to fight terrorism involving all concerned government agencies.

Efforts must be made to assess the threat of new terrorism and to adopt new techniques to deal with it.

Policies and actions against terrorism should be guided by fundamental democratic principles.

Adequate resources should be made available to effectively implement a plan against terrorism, otherwise the cost of failure will be extremely high.

\section{Bibliography}

[1] Dr.sc. Haki Demolli,"TerroriZmi", Prishtine 2002.

[2] Leonard Eeinberg dhe Paul Davis, cited work.

[3] Dr.sc. Haki Demolli, ;"Terrorizmi” Prishtine 2002.

[4] Dr.sc. Haki Demolli, "Terrorizmi", Prishtine 2002.

[5] Paul Eilkinson, "The Strategic Implications of Terrorism", 5 ; taken at http;//is.ci-cect.com.

[6] Dr. Mgnus Ranstorp

[7] Jim Walsh, "Nuclear Terrorism: Risks, Consequences, and Response" in "Countering Terorism: Dimension of Preparedness".

[8] Michal J. Stevens, "What is Terrorism and can Psychology do anything to Prevent it", fq.511, published online in Eiley inter-scince www.interscience.eiley.com

[9] Karl A. Seger, The anti-terrorist handbook: A practical guide to counteraction planning and operations for individuals, businesses and government (Novato, Calofornia:Presidio Press,1990).

[10] Ealter Laqueur, The age of terrorism (Boston:Little,Broen and Company).

[11] Assassination, " taken at http://en.eikipedia.org.eiki/assassination.

[12] Rex A. Hudson, "The sociology and psychology of terrorism", September 1999.

[13] Richard Falk: Ending terrorism, botuar ne "terrorism and political violence", by editor Henry han SHBA,1993.

[14] The International Terrorism a legal critique from Muhamed Aziz Shukri, Vermont 1991. 